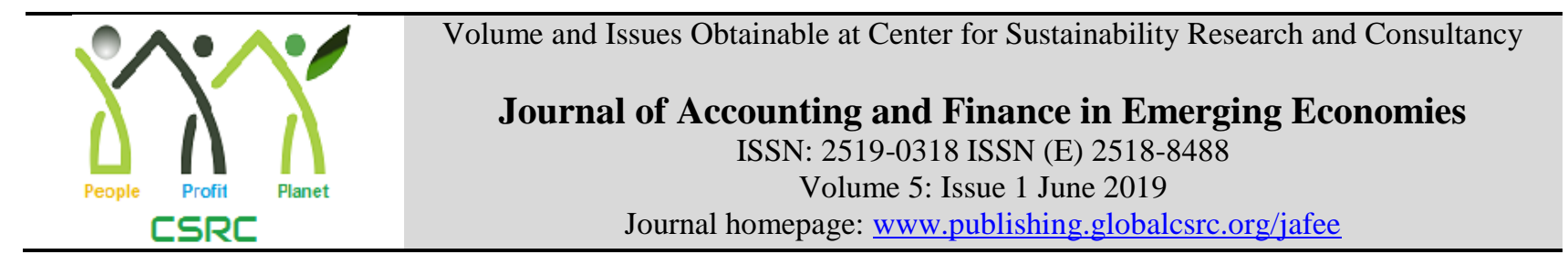

\title{
Socio-Economic Determinants of Employment: A Case study of Pakistan
}

\author{
${ }^{1}$ Muhammad Atif Adeem, ${ }^{2}$ Muhammad Sibt-e-Ali, ${ }^{3}$ Raheel Akhtar \\ ${ }^{1}$ M. Phil Scholar, National Collage of Business Administration \& Economics, Lahore, Pakistan. \\ E. Mail: atifsumbuls@gmail.com \\ ${ }^{2}$ M. Phil Scholar, School of Economics, Bahauddin Zakariya University Multan, Pakistan. \\ E. Mail: ali4bzu@gmail.com \\ ${ }^{3}$ PhD Scholar, School of Management Sciences and Economics, North China University of Water Resources and \\ Electric Power, Zhengzhou, China. E. Mail: mianraheel19@gmail.com
}

\begin{tabular}{l} 
ARTICLE DETAILS \\
\hline History \\
Revised format: May 2019 \\
Available Online: June 2019
\end{tabular}

\section{Keywords}

Employment, Pakistan, ARDL, Unemployment, Economic

Growth.

\section{JEL Classification:}

\begin{abstract}
This research is the foremost determination to investigate the long and short run affiliation amongst the variables of employment. For this purpose we use ARDL bound tests. The data from the period of 1972 to 2016 has been used in this research. These results indicate that employment has statistically significant and positive relationship between the variables of employment. Orders of integration of variables used in this analysis are I (O) and I (1). The results of this study show that per capita of GDP and expenditures of government have significant positive relationship with the employment in both time periods, the short and long run. Thenoteworthyempirical relationship is found in long run between GFCF, while in short period of time it shows destructive relation with employment. While FDI shows a high level of significant and positive relation both in long run and short run. Secondary school enrolment has significant and positive relation with employment in both time periods the long and short run time period. The relationship of money supply with employment in long run is positive while in short run it shows significant but negative relation with employment. Trade and political stability both are the main factors to estimate the strength of an economy. According to this study trade and political stability shows significant and positive relation with employment in long run while in short run both shows negative relationship with employment.
\end{abstract}

(C) 2019 The authors, under a Creative Commons Attribution-Non

Commercial 4.0

Corresponding author's email address: mianraheel19@gmail.com

Recommended citation: Adeem, M. A., Sibt-e-Ali, M. and Akhtar, R. (2019). Impact Socio-Economic Determinants of Employment: A Case study of Pakistan. Journal of Accounting and Finance in Emerging Economies, 5 (1), 71-82

DOI: $10.26710 /$ jafee.v5i1.724

\section{Introduction}

Over the last 20 decades there are tremendous researches on the economic growth. Pakistan is in the list of fast growing eleventh developing country which has high potential to get his name in the world's large economy 
countries in 21stcentury in term of purchasing power parity (PPP). Pakistan is the 25th largest economy in the world. The economy of Pakistan is affected greatly with internal political disputes and rapidly growing population.

Barker defined the unemployment is the condition of no work, while the person who is not in working condition is considered as the unemployed person, currently present for work and is looking for the work. (1999: 165). The rate of unemployment is defined as the amount of person that are unemployed or not in working condition from overall population and then taken the rate in percentage. According to the Human Science Research Council (1985) the unemployment is the situation of no work in which a person wants to do job or work, but he has no work to do will considered as the unemployed person and consists in unemployment. While there is another type of unemployment is hidden unemployment. In this situation, the person wants to do some constructive work but have threat of his ongoing age and keep themselves hide just because how much chance he has or not, or think rather he gets the chance of work or not, is also considered in unemployment.

Unemployment rate in the world is 6.0 percent, instead of fast economic growth of 5.1 percent in 2010 and 4 percent in 2011. According to the ILO, for further four years, global unemployment will remain high with more than 197 million unemployed people around the world. Unemployment has witnessed two folds between 2007 and 2009 in countries such as USA, Ireland and Spain. However, there are some countries like Germany, where unemployment has gone up at constant level in 2008 and 2009. In European Union (EU) and Developed Economies regions, during 2007 1nd 2011, unemployment has distressed the economic conditions. In numerous developing countries such as Sri Lanka, Thailand, Brazil and Uruguay, the rate of unemployment has been fallen during these years.Furthermore, a well performed economy sometimes has to face the dilemma of unemployment. According to Grantas and Koller (2005), this may be the outcome of the challenges of matching those who are looking for job and what is available in the labor market or as a result of mismatching of job training, education level and experience.

Socio-economic is the branch of economics which deals with the study of social behaviors, norms, ethics and social values that influence the economy as a whole. It also analyzes the reasons behind this progress and hinders of the social growth. Social economics refers to the relationship of public and fiscal factors within the society that influence the action of particular group or socioeconomic class. A socioeconomic class is a group of people that have same social and economic status, level of education, profession, and different facilities etc. Socio-economic development is evaluated by factors such as GDP, education, life expectancy, job opportunities, new technologies, law and order, changes in physical environment. The impacts of less effecting factors are also considered, such as personal safety, freedom of association, personal dignity.

\section{Literature Review}

Gilbert et al. (2003) investigated that the increase in crime rate is the main reason of unemployment in our country. The researchers has collected the data from 1978-2008. The researcher applied the test of stationarity in form of unit root $\mathrm{ADF}$ test and Granger Causality test.They concluded that the unemployment is the main problem of increasing the crime rate in the country. Government can utilizes more effective methods to crab the occurrence of violent crime.

Wamuthenya et al. (2010) investigated that the elements of employment in ceremonial and informal sector ofAfrican country named Kenya. The author castoff the secondary data from 1989 to 2001 and applying the empirical MNL model. They found that the education has the strongest impact on the employment. They also illustrated that the sex, marital status, education and household responsibilities are the major determinants that effects employment in urban areas of Kenya and vary by age and gender.

Choi et al. (2008) determined through their study whether there is presence of an environmentalconnection between job pull and generalpsychological disorders at the job-relatedplane and whether the associations is a perplexing effect of socioeconomic condition. To find the results, this study is based on the analysis to measure the relationship as correlations and some regression and graphical analyses to measure the efficiency of model. The findings have proved that the socio and economic conditions are related to the stress of job.

Akinpelu et al. (2013) said the socio-economic determinants of corruption are found in Nigeria. They used the data in the form of time series of variables fromtime period 1980 to 2011. The researchers used Corruption as an independent variable which is measured in Perception Index and formulated through the TI which is considered as 
Transparency International.The researchers revealed that unemployment is one of the major factors that cause corruption in Nigeria. The empirical findings of this concerned research has proved the significant association ofcorruption, GDP and unemployment in long period of time.

Kassa (2011) analyzed the effect of determinants of unemployment at individual and household welfare. The researcher collected the data of 1500 households from 4 major cities of Ethiopia for the period 1994 and 2004. He found from his study that the chances of unemployment increased with age. As the problem of unemployment reduced it would enhance the welfare of the households.

Mahmood et al. (2013) investigated the link between major factors that hurdles the progress of Pakistan. To discover out the long run connection between variables, the researchers applied some techniques like used the methodology of Johansen's test of cointegration and VECM.They also concluded from their study that in Pakistan, interest rate and inflation do not influence significantly the unemployment rate. The rate of unemployment is affected by other factors like education level, peace and economic growth.

Aurangzeb et al. (2013) examined the employment level in China, India and Pakistan by following the elements of macroeconomic. Thedata has been used over the time in years 1980 to 2010. In Pakistan,foreign investment, poverty and unemployment rates have the noteworthy and constructive association with GDP of Pakistan.Moreover, the findings related to granger causality test proved that the two way causation is not exists among the concerned variables of this study.

Mahmood et al. (2014) elaborated that the Pakistan' economy in terms to the association among the growths of Pakistan economy and unemployment in Pakistan. This research has followed the data of concerned variables over the time in years of 1990 to2010.The result of research study shows that unemployment have significant association with selected independent variableslike foreign investment, while GDP, inflation, population growth, budget deficit, literacy rate and labor force which are included as explanatory variables.

Tahir et al. (2012) discussed how formal sectors wages affects informal employment and growth. The data was collected from five towns of Lahore from 2001-2010. The results showed that in informal industrial sectors, there is positive effect of population growth on employment. While, in informal sectors GDP growth rate has negative effect on employment.

Aqil et al. (2004) investigated the most important issue of macroeconomics and among them unemployment is most important issue. The data from year 1980 to 2010 has been used in this study. Their result showed that the significance is found of foreign investment and growths of population in terms to unemployment. While this significance is found destructive in terms to unemployment. On the other hand the growth of GDP has no effect on unemployment which is also evidenced among inflation and unemployment.

\section{Data and Methodology}

In this study, secondary data have been used. The source of collecting the data is World Bank and Pakistan Economic Survey. Our research covers the annual data over the period of 1972 to 2015.

\subsection{Concept of Variables used in the Study}

Different variables are used to measure the socio-economic determents of employment in developing economy Pakistan. Following are the main variables and their explanation.

\subsubsection{Employment (EMP) (Dependent Variable)}

Employment is the economic situation in which the whole population that is active is taken under consideration and included the employed person and unemployed too. Its size differs as rendering to the definitions of unemployment used. The officially used rate of employment is computed in proportion. Employment rate is theamount of employed people from total population and taken in percentage. The consequences of unemployment are quite deadly. Due to unemployment not only the individual suffers but his social life has to suffer. 


\subsubsection{Secondary School Enrolment (SSE)(Independent Variable)}

A recent socio-economic survey of landscape of Pakistan exposes many deficiencies in our education system. The gross enrolment is less than $25 \%$ in elementary education, $36 \%$ of population live in poverty and labor force is $35 \%$ of the population. The literacy rate for the population recorded at 58\% during 2011-12, according to the Pakistan Social and Living Standard Measurement Survey (PSLM) 2011-2012. (Highlights of Economic Survey 20112012). The main goals of National Education Policy are to focus the issues of access of education, quality and equity at all levels.

\subsubsection{Foreign Direct Investment (FDI) (Independent Variable)}

One of the main advantage of the FDI is it enhance growth and technology is traded in the form of new ideas and techniques. DFI is carried out through MNCs and they are the key source of technology diffusion. According to the Economic Survey 2012-2013 the FDI in Pakistan recorded at \$ 853.5 million during July-April 2012-2013. It records an increase of $29.7 \%$ as compared to the last year where it stood at $\$ 658.2$ million.

\subsubsection{Trade (Shape of Imports plus Exports) (Independent Variable)}

International trade is beneficial for both importing and exporting countries. The economic growth of the country increases as its trade increases. The researchers originate a positive and weightyassociation between openness of trade and growth of Pakistan's economy. Moreover, the open economy index is indicated by the ratio of exports to GDP, it is calculated that a higher ratio shows a higher open economy while a lower ratio depicts to a close economy and limited trade policies.

\subsubsection{Political Stability (POL) (Independent Variable)}

The two main components of the government's strategy are to increase the demand for labor by enhancing output and labor absorption ability by promoting special employment programmers; such as technological change, product innovation, promoting jobs programmers, expanding the investment environment, involvement in specified areaslike agriculture, infrastructure and mining.

\subsubsection{Gross Domestic Product per Capita (GDPPC) (Independent Variable)}

GDP is measured in terms to per capita, per capita of GDP is the final amount of produced goods and services which are produced by per person. Per capita of GDP indicates the per person income which is related to the growth in economy. GDP in terms to per capita is generated when the total income is divided by the total population of the economy.

\subsubsection{Gross Fixed Capital Formation (GFCF) (Independent Variable)}

Gross fixed capital formation (GFCF) indicates the enhancement of physical assets. GFCF is fixed rate of increase in the assets that are in physical form. While this increment in physical assets is related to the increment in future investment or increment in capital stock. According to the economic survey of Pakistan, the capital formation is found 1647268 Million Rupees in fiscal year 2016 which was recorded 1558295 Million rupees in fiscal year 2015.

\subsubsection{Money Supply (M2) (Independent Variable)}

The supply of money is related to the circulation of liquidity money in the country. The currency stock, and instruments of liquidity of money are considered as the money supply.According to the reference of stock of money, the coins, cash, saving accounts, business accounts and individual accounts for investment and payments in short period of time are also considered as the supply of money.

\subsubsection{Government Expenditure (GE) (Independent Variable)}

Government expenditures are the expenses of government in the form of consumption, investment, as well as transfer payments are also include in government expenditures. The government collect taxes for the expenditures and government expenses. Government mostly use their expenditures on capital stock and for the formation of capital stock. Moreover, the government expenditures are in the shape of infrastructure development. The government use their capital stock and other expenditures form for the development.

\subsection{Model Specification}

This is very importantstep to measure the bond of employment which is dependent variable with economic growth and its indicators as independent variables. Different variables are used to get out the relationship between employment (dependent variable) and the other independents variable in Pakistan. 
Following are the main equation

$$
E M P=f(G D P P C, S S E, F D I, G F C F, M 2, G E, T R A D E, P O L)
$$

where

$\mathrm{EMP}=$ Employment Rate (Dependent Variable)

GDPPC $=$ Per Capita of Gross Domestic Product

SSE $=$ Enrollment in Secondary School (Annual Percentage)

TRADE $=$ Trade (Share of Import Plus Export as Percentage of GDP)

FDI $=$ Foreign Direct Investment (Percentage of GDP)

POL=Political Stability (Index Annual Percentage)

GFCF=Gross Fixed Capital Formation

M2 = Money Supply

$\mathrm{GE}=$ Government Expenditure

Now this study can develop the econometric model from the above mathematical model.

$\mathrm{EMP}=\gamma 0+\gamma 1 \mathrm{GDPPC}+\gamma 2 \mathrm{GFCF}+\gamma 3 \mathrm{FDI}+\gamma 4 \mathrm{SSE}+\gamma 5 \mathrm{M} 2+\gamma 6 \mathrm{GE}+\gamma 7 \mathrm{TRADE}+\gamma 8 \mathrm{POL}+\gamma 9 \mathrm{GE}+\varepsilon$

Where $\varepsilon=$ error term.

\section{Result and Discussion}

This is the very important segment of the research. This section is based on the statistical well-being of empirical model. The empirical model is measured in statistical term and describes as the strength of model in statistical form. This analysis tells about the data, their quantitiesimportance and empirical estimation of the data. Following are the table which tells us about the descriptive statistic of all the variables used in our research.

Table 1 Descriptive Statistics of Different variables used in the research

\begin{tabular}{|l|l|l|l|l|l|l|l|l|l|}
\hline & EMP & GDPPC & GFCF & FDI & SSE & M2 & GE & TRADE & POL \\
\hline Mean & 33.57 & 2.43 & 16.12 & 0.74 & 67.76 & 42.23 & 106.67 & 33.80 & 0.64 \\
\hline Median & 28.62 & 2.14 & 16.90 & 0.55 & 61.29 & 41.43 & 107.59 & 33.57 & 0.67 \\
\hline Maximum & 44.89 & 6.60 & 19.24 & 3.67 & 94.81 & 49.19 & 112.39 & 38.91 & 0.78 \\
\hline Minimum & 25.98 & -1.64 & 11.58 & -1.18 & 47.89 & 36.71 & 98.97 & 27.72 & 0.07 \\
\hline Std. Dev. & 7.41 & 1.99 & 1.95 & 0.94 & 16.07 & 3.47 & 4.07 & 2.71 & 0.13 \\
\hline Skewness & 0.38 & 0.15 & -0.88 & 1.29 & 0.43 & 0.32 & -0.31 & -0.26 & -2.40 \\
\hline Kurtosis & 1.34 & 2.31 & 2.86 & 5.51 & 1.63 & 1.97 & 1.84 & 2.91 & 10.02 \\
\hline Jarque-Bera & 5.59 & 0.95 & 5.14 & 21.69 & 4.40 & 2.46 & 2.91 & 0.48 & 120.39 \\
\hline Probability & 0.06 & 0.62 & 0.08 & 0.00 & 0.11 & 0.29 & 0.23 & 0.79 & 0.00 \\
\hline Sum & 1342.87 & 97.02 & 644.64 & 29.62 & 2710.56 & 1689.09 & 4266.64 & 1352.13 & 25.54 \\
\hline Sum Sq. Dev. & 2141.28 & 154.60 & 147.83 & 34.81 & 10070.20 & 468.67 & 646.68 & 286.91 & 0.69 \\
\hline & & & & & & & & & \\
Observations & 40.00 & 40.00 & 40.00 & 40.00 & 40.00 & 40.00 & 40.00 & 40.00 & 40.00 \\
\hline
\end{tabular}

The descriptive analysis tells us about the mean, median min, max, std. dev, and the total number of observation in the research. The above findings of table of descriptive summary given the average value of employment about 33.57 and its std. dev is 7.41. The mean value of FDI is 0.71 , median is 0.55 and std. dev is 0.94 . The mean value of trade is 33.80 , median is 33.57 and std. dev is 2.71 . The mean vale of M2 is 42.23 , median is 41.43 and std. dev is 3.47. The total number of observation is 40 in this research.

Table 2 is used to check the problem of multicollinearity estimated the correlation matrix. This table shows the correlation coefficient among variables.

\begin{tabular}{|l|l|l|l|l|l|l|l|l|l|}
\hline & EMP & GDPPC & GFCF & FDI & SSE & M2 & GE & TRADE & POL \\
\hline
\end{tabular}




\begin{tabular}{|l|l|l|l|l|l|l|l|l|l|}
\hline EMP & 1.00 & & & & & & & & \\
\hline GDPPC & 0.01 & 1.00 & & & & & & & \\
\hline GFCF & 0.48 & -0.09 & 1.00 & & & & & & \\
\hline FDI & 0.40 & -0.19 & 0.40 & 1.00 & & & & & \\
\hline SSE & 0.87 & -0.01 & -0.66 & 0.24 & 1.00 & & & & \\
\hline M2 & 0.01 & -0.11 & 0.40 & 0.59 & -0.10 & 1.00 & & & \\
\hline GE & 0.27 & 0.22 & 0.03 & -0.28 & -0.17 & -0.43 & 1.00 & & \\
\hline TRADE & 0.40 & -0.04 & 0.38 & 0.22 & -0.23 & 0.29 & 0.08 & 1.00 & \\
\hline POL & 0.31 & -0.03 & -0.26 & 0.16 & 0.44 & -0.13 & -0.22 & 0.12 & 1.00 \\
\hline
\end{tabular}

The above table shows the explanation of multicollinearity. The correlation between GDP Per Capita with other explanatory variables is weak. The correlation of GDPPC with employment is weakly positive with a value of $0.01 i$-e it indicates weak relationship with employment. There exists negative and weak linear correlation between FDI and GDPPC. Here exists a strong optimistic linear connectionamong secondary school enrolment and employment with a value of 0.87 . It means that as the secondary school enrolment increases the employment level also increases. The association between money supply, government expenditure and politicalsatiability with other explanatory variables is also weak. The value of correlation of money supply with FDI shows positive and moderate linear relationship. The above table indicates that present exists weak linear correlation among the all variables of employment.

ARDL Test:

Table 3the F-test for Co-integration

Significance Level

\begin{tabular}{lcccccccc} 
& $1 \%$ & & $2.5 \%$ & & $5 \%$ & \multicolumn{3}{c}{$10 \%$} \\
& & & & & & & & \\
F-Statistics & $\mathrm{I}(0)$ & $\mathrm{I}(1)$ & $\mathrm{I}(0)$ & $\mathrm{I}(1)$ & $\mathrm{I}(0)$ & $\mathrm{I}(1)$ & $\mathrm{I}(0)$ & $\mathrm{I}(1)$ \\
5.917085 & 2.79 & 4.1 & 2.48 & 3.7 & 2.22 & 3.39 & 1.95 & 3.06
\end{tabular}

(Source: Authors' calculation)

The table 3 interprets the measurement of acceptance of our null hypothesis. The null hypothesis is "there exist no long run relationship between the variables of employment". It is obvious from the table the value of F-Statistics is greater than the upper bounds I(1), it means that there exist long run co integration between the variables at different levels of significance. The probability value of upper bound at $10 \%$ significance level is 3.06 i.e. less than the value of F-Statistics, so it indicates the long run cointergration exists between the variables. While at the 5\% level of significance the value of probability of upper bound is 3.39 it is also lower than the calculated value of FStatistics.

\subsection{Long- Run Estimating Results:}

Now we find out the long run coefficients of ARDL model. The outcome of the estimated long run coefficients are given in the following Table.

Tableshows the long run coefficients, Standard error, t-statistics and probabilities of explanatory variables. We estimated the eight variables in which the employment is depending on the elements of economic growth like money supply, GDP per capita, secondary school of enrollment, trade (share of import plus export), and foreign direct investment $\%$ of GDP, political satiability index annual percentage, government expenditure and gross fixed capital formation. 


\section{Table 4 Long RunCo integrating Coefficients}

\section{Dependent variable Employment (EMP)}

\begin{tabular}{lllll} 
Variable & Coefficient & Std. Error & t-Statistic & Prob. \\
GDPPC & 0.2696 & 0.1296 & 2.0795 & 0.0476 \\
FDI & 7.7571 & 4.3807 & 1.7707 & 0.0883 \\
SSE & 1.3758 & 0.7011 & 1.9624 & 0.0594 \\
M2 & 1.3144 & 0.8457 & 1.5541 & 0.1322 \\
GE & 2.3936 & 1.2680 & 1.8877 & 0.0703 \\
TRADE & 0.9091 & 0.5401 & 1.6831 & 0.1043 \\
POL & 0.2866 & 0.1326 & 2.1613 & 0.0401 \\
GFCF & 0.8104 & 0.0899 & 9.0065 & 0.0000 \\
C & 0.2056 & 0.1474 & 1.3953 & 0.1747 \\
\hline$* * *$ and $* * *$ show significance at $1 \%, 5 \%$ and $10 \%$ level. & \\
\hline
\end{tabular}

The empirical findings of GDP per capita is estimated as constructive and noteworthy. Which shown in the above Table. The value of GDPper capita coefficient is 0.2696 at $5 \%$ level of significance, which means that $1 \%$ increase in GDPPC would result in 0.2percent increase in employment. Savings of the individual increases it will impact on personal and public investments, as the investment increases it will influence the per capita income of the economy.As a result with the increase in the employment opportunity the gross domestic product increases. The government of the country has to change the policies to reduce the unemployment. The Okun's law describe the association among the losses in production and unemployment. The Okun's law suggests the positive impact of gross domestic production employment. The empirical studies by Aqil et al. (2014) evidenced the same findings among gross domestic product and unemployment. Aurangzeb et al. (2013) found that the ineffective use of foreign direct investment and poverty is related to the economic growth, as well as the unemployment is also affected by the GDP of Pakistan. While, all these indicators are also affected the GDP.

Foreign direct investment shows statistically significant relation with employment at 5\% level of significance. It is clear from the table that 1 percent increase in FDI will direct to raise in employment by $7.7 \%$.It'sindicationsis that there is a strong affiliationof foreign investment with employment.In any economy, FDI plays a vital role. In the suitable and peaceful economy, the foreign investors are more interested to invest resulting in increment in aggregate demand, so labor demand also increases. As a result the employment level increases. The empirical studies by Bhaumik at el (2004) is also evidenced the same findings. Ledyaeva et al. (2008), Aqil at el. (2014), Ristanovic (2010), J. Tolo(2011), Distsakis et al. (2002) found the optimistic association between foreign direct investment and employment.

Education plays a role of a backbone for any economy. From the table 6.4, it is clear that 1 percent increase in SSE will result in 1.3 percent increase in employment. If an economy pays serious attention towards the establishment of educational sectors and the secondary school enrollment its growth level automatically enhanced. Because more educated and skillful persons leads the economy on the path of growth. As a result employment opportunities level increases. Enrollment management theory supports the relationship of education with employment. Enrollment Managementtheory is used frequently in higher education to describe well-planned strategies and tactics to shape the enrollment of an institution and meet established goals. The empirical studies by Barro J.R (2001)Ristanovic (2010) J.ToloDec(2011) Distsakis et al. (2002) found the positive relationship between Secondary school of enrollment and employment.

The value of Money supply coefficient is 1.3144 . Money supply is statistically significant at $10 \%$ level of significance. From the table, it is concluded that 1 percent increase in money supply would result in $1.3 \%$ increase in employment level.As the supply of moneyin Pakistan's economy upsurges, it will increase the level of consumption at individual level so aggregate supply increases. By the tax cut and less government spending, the 
economy tends to contract in to the recession so increases the money supply.The investment level increases. It will result in increases the employment level in the economy. Expansionary fiscal and monetary policies are used to tradeoff between reducing unemployment and increase the price level. It will result in the attainment of level of full employment. The relationship of employment and money supply is explained in Quantity Theory of Money (QTM).

Government expenditures show significant relationship with employment at 5\% of significant level, means that 5\% increase in government expenditures would increase in employment by $2.3 \%$. As the government increases its expenditure level on the betterment of the economy, so aggregate demand will boost, it will automatically open the path of employment.The relationship between employment and government expenditures is supported by The Theory of Public expenditure.In the 20th century, John Maynard Keynes argued the role of public expenditure in determining levels of income and distribution in the economy. The empirical studies by Nabila et al. (2011), Barroo (2003) showed positive relationship between the government expenditures and employment.

Increment in trade by $10 \%$ would results an increase of 0.9 percent in employment. The level of significance is $10 \%$. It is clear from the table that the existence of relationship between trade and employment is found in long time period. If the government of the economy reduces the trade barriers, the opportunity of exports of goods increases. It results in the enhancement of the investment and production. With the increase in the production, output increases and as a result the employment level also increases. It will automatically caste positive impact on the growth of the economy. This concept is supported by Classical Trade Theory. The empirical studies by Cheema et al. (2014), Dewan et al. (2011), Muhammad Shahbaz et al. (2008) foundpositive relationship between trade and employment.

The value ofpolitical satiability coefficient is 0.2866 which indicates that $1 \%$ increase in political stability would results in increase in employment by 0.2 percent. It is shown in the table that there exists significant long run association between POL and employment at $10 \%$ level of significance. Political stability of the country is a parameter of growth. If a country's environment is more peaceful it will open the ways for public and local as well as foreign investors to invest in that economy. People feel more secure to invest in. As a result the employment level increases and the growth of the economy also increases. This concept goes with the Political Stability Index Theory. Political stability refers to stability where politics was extremely predictable. This result is consistent with those of Cheema et al. (2014) empirical studies by Frankle et al. (1997) found the positive relationship betweenpolitical satiability and employment.

The value of gross fixed capital formation coefficient is 0.8104 . It is statistically significant at $1 \%$ level of significance. The value of slope is $81 \%$. It is obvious from the table that $1 \%$ increase in GFCF would result in 0.8 percent increase in employment level. Capital formation for a country is considered as a measurement of the progress of its economy. With the boost of capital formation the real GDP increases, in return the value of national output increases, the investment also increases, different firms employ more workers so creating more employment opportunities. It will directly influence the employment in long run. So it shows a constructive increment in employment because ofcapital formation in fixed term in long run. The empirical studies by Distsakis et al. (2002) K.H. Ndambiri (2005) found the positive relationship between gross fixed capital formation and employments.

\subsection{Short Run Co- integrating Coefficients: 4.2.1 Error Correction Results:}

In this step of empirical estimation of model by using error correction unrestricted technique, the dependent variable is employmentD (EMP). "D" represents the first difference of the variable. The change in gross fixed capital formation has negative impact on employment. The change in foreign direct investment has negative effects on employment. The change in secondary school of enrollment is negatively related with employment. The change in money supply has negative association with employment. The change in trade value added has negative impact on employment. The change in political satiability value added has negative impact on employment . The change in gross domestic product par capita, foreign direct investment; government expenditure has positive effects on employment. 
Table 5: Empirical Outcome of Unrestricted ECM

Dependent variable: EMP

$\operatorname{ARDL}(1,0,1,2,2,0,2,0,0)$

\begin{tabular}{|l|l|l|l|l|}
\hline Variable & Coefficient & Std. Error & t-Statistic & Prob. \\
\hline $\mathrm{D}($ GDPPC $)$ & 0.2056 & 0.1473 & 1.3953 & 0.1747 \\
\hline $\mathrm{D}(\mathrm{GFCF})$ & -0.4273 & 0.3295 & -1.2969 & 0.2060 \\
\hline $\mathrm{D}(\mathrm{FDI})$ & 0.2998 & 0.6994 & 0.4287 & 0.6717 \\
\hline $\mathrm{D}(\mathrm{FDI}(-1))$ & -1.7664 & 0.8343 & -2.1171 & 0.0440 \\
\hline $\mathrm{D}(\mathrm{SSE})$ & 0.2429 & 0.1538 & 1.5796 & 0.1263 \\
\hline $\mathrm{D}(\mathrm{SSE}(-1))$ & -0.2866 & 0.1326 & -2.1613 & 0.0401 \\
\hline $\mathrm{D}(\mathrm{M} 2)$ & -0.2492 & 0.1236 & -2.0154 & 0.0543 \\
\hline $\mathrm{D}(\mathrm{GE})$ & 0.2696 & 0.1296 & 2.0795 & 0.0476 \\
\hline $\mathrm{D}(\mathrm{GE}(-1))$ & 0.2950 & 0.1269 & 2.3242 & 0.0282 \\
\hline $\mathrm{D}(\mathrm{TRADE})$ & -0.1723 & 0.1074 & -1.6041 & 0.1208 \\
\hline $\mathrm{D}(\mathrm{POL})$ & -6.2065 & 2.7413 & -2.2640 & 0.0321 \\
\hline CointEq(-1) & -0.1895 & 0.0899 & -2.1071 & 0.0449 \\
\hline
\end{tabular}

Table shows that the convergence and the divergence of variables around the dependent variable. The convergence means movement towards the equilibrium and divergence means away from the equilibrium. The ECM model consists of speed of adjustment tools to restore the equilibrium. The convergence and the divergence interpreted by the sign of coefficient of co integration equation. If the sign is negative, it means the variables are convergence. If the sign is positive, it means the variables are divergence. The value of parameter of co-integration equation is 0.1895. The value -0.1895 shows that the adjustment of error is moderate which is done byECM tools of adjustment. The value of ECM significance level is measured in 5 percent. Which is showing that the error is stabled in each year. The value of ECM is -0.18 which is negative and significant and showing that the 18 percent of error is stabled in each year by measuring it significantly. This significance and productive reduction in error has provide the stability in long period of time which was arrived by short period. The findings are evidenced by Khan and Hye (2010)and Cheema et al. (2014). While results of short run coefficient show that change in gross domestic product per capita (GDPPC), foreign direct investment (FDI), secondary school enrollment (SSE), government expenditures (GE) have positive impact on change in employment rate. While gross fixed capital formation (GFCF), money supply (M2), trade (TRADE) and political stability (POL) show negative impact on the change in employment rate.

\section{Conclusion and Recommendations}

This study is to examine the socio-economic determinants of employment in Pakistan during the period of 1972 to 2015, analyzing the data by using Augmented Dicky Fuller and ARDL technique. The main determinants of employment that is being used in this study are: growth rate of labor force, growth rate of capital, secondary school of enrollment, investment from foreign, openness of trade, debt, instability in political terms, life expectancy and urbanization.

In this study the dilemma of unemployment has been supported with different employment theories such as general theory of employment, classical theory of employment, neo-classical concept of output and employment and Keynes theory of employment. In classical theory, Keynes gave the concept that the level of full employment is achieved by aggregate demand and not by price level. He discussed in this theory that it is wrong concept that the full employment state is self-maintaining or self-adjusting. While, the founders of classical theory that are Adim Smith, J.S Mills, Malthus J.B and N.W focused on the self-adjusting economy. They are on the view that any fluctuation in the economy eventually moves towards the level of full employment. The situation of overproduction and unemployment is temporary situation of the economy. According to the Keynes theory of employment, the level of full employment is estimated by the aggregate supply and demand that further determines the effective demand.

Keynes in his theory stated that aggregate demand and aggregate supply together determine the effective demand, which estimates the level of employment in the economy.If national income increases consumption rate also 
increases. While, low consumption rate result in the decrease in effective demand. This gap between the consumption and income is minimized by increase in investment. This will lead to the increase in effective demand which further leads in the reduction of unemployment and bring the economy at the level of full employment. Neoclassical economists argued that any change in monitory and fiscal policies that effects the aggregate demand does not affect output and employment. They focused on rational expectation on the basis of all existing information about all variables rationally and intelligently.

Being an agricultural rich country Pakistan has to face many problems to drive on the path of modernization. With the passage of time and better management the government of Pakistan is able to get in the list of fast developing countries. This study observed that education participate its positive partto progress the economy and toattainthe job. There is need to invest more in school education so it eventually effect employment rate. With respect to age, there is $U$ shaped pattern of unemployment. Among the youth there is higher rate of unemployment, moderate for the ages of middle and higher for the ages of old labor income composes the major source of income for the majority of individuals and households. The contribution in the market is restrained without income. The unemployed person has limited access to money and limited approach towards the standard of goods and services they can purchase. The unemployed person does not have excess income to save for security, education, holidays and lifestyle improvement. He cannot afford the status of well-paid employed worker so they are not able to contribute in the market activities. To meet the minimum living standards he has to depend upon his savings, family transfers, and loan and sometime on black economic activities.

- Strengthen especial employment programs.

- There should be upsurge in per capita GDP in this way that it exposes the several prospects of employment.

- Investment should be increased in such programs of technical education so that the literacy level would increase, it would indirectly increase the growth as well as employment.

- To boost up the employment the government must take serious steps by increasing productivity.

- There are two main elements of government policies.

- The most important is to increase the demand for labor through the boosting of both output and capacity of labor absorption with the solidification of employment plans.

- There should be protection of jobs in private sectors through urging work reorganization, acceptance of technological changes, innovation and by focused interventions in the specific sectors.

- The second element is to strengthen the employability of labor by giving them chances to get technical education and training and by improving the accessibility of skills.

- Government should give special attention to weak group such as women, young and fresh workers and disabled persons.

\section{References}

A Case Study of Pakistan.32 | J. Glob. \& Sci. Issues, Vol 1, Issue 2, (June 2013) ISSN 2307-6275.

Agarwal.D. M. K and Dhakal D.R.C (2009) Socio-economic Determinants of Income Generation in the Informal Sector of Nepal - A Case of Chitwan District. Session Number: Session 7 (Plenary) September 25, 9:0010:30.

Akinpelu, Akano.Y, Ogunseye, O.T, Bada, Agbeyangi, B.A (2013) The Socio-Economic Determinants of Corruption in Nigeria. European Journal of Humanities and Social Sciences ISSN 2220-9425 Vol.19, No.1 2013

Aqil.M, Qureshi.A.M, Ahmed.R.R, Qadeer.S(2014) Determinants Of Unemployment In Pakistan. IJPSS Volume 4, Issue 4 ISSN: 2249-5894.

Arvanitidis.P, Pavleas.S, Petrakos.( January 2009) Determinants of Economic Growth: The View of the Experts, Discussion Paper Series, 15(1): 1-22.

Aurangzeb, Asif.K (2013) Factors Effecting Unemployment: A Cross Country Analysis. International Journal of Academic Research in Business and Social Sciences January 2013, Vol. 3, No. 1 ISSN: 2222-6990.

Azam.M and Khattak.N. (2009) Empirical Analysis of Determinants of Economic Growth in Pakistan, 19712005.Sarhad J.Agric .Vol.25, No.2, 2009.

Barro.J.R (1996) Determinants of Economic Growth: A Cross-Country Empirical Study, NBER Working Paper 5698. 
Bhaumik.S.K, Meyer.K, (2004) Determinants of Employment Growth at MNEs: Evidence from Egypt, India, South Africa and Vietnam. ZA DP No. 1272 August 2004.

Cheema.A.R, Atta.A (2014) Economic Determinants of unemployment in Pakistan: Co-integration Analysis. International Journal of Business and Social Science Vol. 5 No. 3; March 2014.

Choi.B, Clays.E, Bacquer.D.D, Karasek.R (2008) Socioeconomic status, job strain and common mental disordersAn ecological (occupational) approach. SJWEH Suppl2008;(6):22-32.

Eita.J.H, Ashipala M.J (2010) Determinants of Unemployment in Namibia. International Journal of Business and Management. Vol. 5, No. 10; October 2010

Faisal.I, Nawaz.Y, Asim.M, Hashmi.A.H (2013) Socio-Economic Determinants of Rural Migrants in Urban Setting: A Study Conducted at City Sargodha, Pakistan.Academic Journal of Interdisciplinary Studies. Vol 2 No 1 (March 2013).

Faridi Z.M, Chaudhry I.S, Anwar.M (2009) The Socio-Economic and Demographic Determinants of Women Work Participation in Pakistan: Evidence from Bahawalpur District. A Research Journal of South Asian Studies Vol. Vol. 24, No. 2, July 2009, pp. 351-367

Fischer.G, Shah.M, Tubiello.N.T and Velthuizen.V.H (2005) Socio-economic and climate change impacts on agriculture: an integrated assessment, 1990-2080, Phil. Trans. R. Soc. Bdoi:10.1098/rstb.2005.1744.

Frankel.A.J (1997) Determinants of Long Term Growth, Background Paper for the Morning Session of the Meeting of the Asia-Pacific Economic,Cooperation Economic Advisers, Vancouver, Canada, November 20, 1997

Gilbert.K, Sookram.S (2003)The Socio-economic Determinants of Violent Crime in Jamaica

Gillani.D.K, Asgher.N, Farooq.F (2014) Socio-Economic Determinants of Self-Employment: Evidence from Southern Punjab (Pakistan). Pakistan Journal of Social Sciences (PJSS) Vol. 34, No. 2 (2014), pp. 511-522

Gregorio.D.J, Lee.W.J (1999) Economic Growth In Latin America: Sources And Prospects*

Ikramullah, Shair.G, NaeemurRehman (2011) Economic and Social Dimensions of Rural-Urban Migration in Pakistan: Results froma Recent Survey in the North West Pakistan. International Journal of Business and Social Science vol. 2 No. 3 (special issue - January 2014)

Ilyas.N (2015) SOCIO-ECONOMIC PROBLEMS FACED BY YOUTH DUE TO UNEMPLOYMENT IN RAWALPINDI The Explorer: Journal of Social Sciences ISSN: 2411-0132, Vol-1, Issue (1):25-28

Kassa.F.A (2011) Unemployment in urban Ethiopia: Determinants and Impact on Household Walfare. Project No 2011:105

Kill.A (2013) Determinants of employment-based private health insurance coverage in Denmark Nordic Journal of Health Economics Online ISSN: 1892-9710

Kim.S (2014) Socio-Economic Determinants of China's Recent Economic Growth. Journal of Reviews on Global Economics, 2014, 3, 101-116.

Ledyaeva.S, Linden.M (2008) Determinants of Economic Growth: Empirical Evidence from Russian Regions, The European Journal of Comparative Economics. Vol. 5, n. 1, pp. 87-105 ISSN 1722-4667

Magidu.N (2010) Socioeconomic Investigation into Determinants of Labour Force Participation in Labour Markets: Evidence from Uganda. (May 2010).

Mahmood.T, Ali.A, Akhtar.N, Iqbal.M, Qamar.S, Nazir.H.Z, Abbas.N, Sana.I (2014) Determinants Of Unemployment In Pakistan: A Statistical Study. International Journal of Asian Social Science ISSN: 22245139 . 
